\title{
Purification and Properties of Two Polygalacturonases from Trichoderma koningii
}

\author{
By C. FANELLI \\ Orto Botanico Institute, University of Rome, Italy \\ AND M. G. CACACE \\ Laboratory of Molecular Embryology, Arco Felice, Naples, Italy \\ AND F. CERVONE \\ Institute of Plant Pathology, University of Naples, Portici, Italy
}

(Received 11 July 1977)

\begin{abstract}
Two inducible polygalacturonases (PG-1 and PG-2) from culture filtrates of Trichoderma koningii were purified to homogeneity by $\mathrm{CM}$-cellulose chromatography and isoelectric focusing in a narrow $\mathrm{pH}$ range ( $\mathrm{pH} 6$ to 8 ). They were both hydrolytic enzymes classifiable as endopolygalacturonases [poly(1,4- $\alpha$-D-galacturonide) glycanohydrolase; EC 3.2.1.15]. PG-1 and PG-2, focusing at pH 6.41 and 6.57 respectively, each consisted of a single polypeptide chain having an apparent molecular weight of 32000 as determined by gel filtration on Sephadex G-100; they were both glycoproteins and had carbohydrate contents of 0.033 and $0.062 \mathrm{mg}$ sugar $(\mathrm{mg} \text { protein })^{-1}$ respectively. When the isoenzymes were incubated with different plant tissues, they were not absorbed by any of them.
\end{abstract}

\section{INTRODUCTION}

In a previous report it was shown that some isolates of Trichoderma koningii Oud. produce an extracellular endopolygalacturonase activity (Fanelli \& Cervone, 1977). Endopolygalacturonase plays an important role in the infection of plant tissues by phytopathogenic fungi since it may mediate host recognition by such host-specific fungi. Recognition could involve receptor proteins in the plant tissue which specifically absorb the enzyme (Cervone, Scala \& Scala, 1977a).

Trichoderma koningii, a saprophytic fungus, does not cause disease in plants although it produces polygalacturonase and other enzymes that degrade all the important components of plant cells. We have therefore investigated the properties of the polygalacturonase from this non-pathogenic fungus. In this paper we report the purification to homogeneity and the characterization of two endopolygalacturonases [poly(1,4- $\alpha$-D-galacturonide) glycanohydrolase; EC 3.2.1.15] from cultures filtrates of $T$. koningii.

\section{METHODS}

Fungus culture. Trichoderma koningii Oud., isolate CF-1 (Ivory Coast), was surface-cultured for $6 \mathrm{~d}$ at $23{ }^{\circ} \mathrm{C}$ in a liquid medium containing $\left(\mathrm{gl}^{-1}\right): \mathrm{KH}_{2} \mathrm{PO}_{4}, 0.5 ; \mathrm{MgSO}_{4} .7 \mathrm{H}_{2} \mathrm{O}, 0.5 ; \mathrm{NH}_{4} \mathrm{Cl}, 0.5 ; \mathrm{FeCl}_{3}, 0.005 ;$ citrus pectin, $10 ; \mathrm{pH}$. The mycelium was removed by filtration through HA Millipore filters $(0.45 \mu \mathrm{m}$ pore size). The culture filtrate was centrifuged at $3000 \mathrm{~g}$ at $4{ }^{\circ} \mathrm{C}$ for $20 \mathrm{~min}$ and then used for enzyme purification.

Chemicals. Citrus pectin was obtained fron NBC, Cleveland, Ohio, U.S.A.; sodium polypectate and D-galacturonic acid from K\&K Laboratories, Plainview, New York, U.S.A.; dinitrosalicylic acid, thiobarbituric acid and bromophenol blue from Merck; CM-cellulose and 3MM chromatographic paper from Whatman; and ampholine carriers from LKB. All other chemicals were reagent grade. 
Polygalacturonase assay. Enzyme activity was determined viscometrically using $0.6 \%(\mathrm{w} / \mathrm{v})$ sodium polypectate in McIlvaine's buffer ( $35 \mathrm{~mm}$-phosphate) pH 5.0. Relative viscometric units $\left(U_{\mathrm{v}}\right)$ were calculated as previously described (Cervone et al., 1977b). Where indicated, polygalacturonase activities were also determined by measuring the formation of reducing groups. The hydrolysis of glycosidic bonds was followed by reducing end-group analysis using the dinitrosalicylic acid procedure (Miller, 1959). As the complete hydrolysis of the substrate produces reducing groups corresponding to the nominal monomer concentration, this latter value was assumed to be $100 \%$ of substrate degradation.

Ultrafiltration. The culture filtrate was concentrated by ultrafiltration in a model LP-1A Amicon Filtration Apparatus using UM-10 Diaflo membranes.

Isoelectric focusing. Experiments were performed in an LKB 8100 column, cooled at $4{ }^{\circ} \mathrm{C}$, and in the $\mathrm{pH}$ range 6 to 8 in a stabilizing linear sucrose gradient ( 0 to $40 \%$,w/v). Focusing was obtained in $36 \mathrm{~h}$, applying a constant voltage of $1000 \mathrm{~V} ; 2.0 \mathrm{ml}$ fractions were collected from the column for $\mathrm{pH}$ and activity determinations.

Sodium dodecyl sulphate (SDS)-gel electrophoresis. Polyacrylamide gel electrophoresis in the presence of $0.1 \%$ (w/v) SDS was performed according to Laemmli (1970) using $3 \%(\mathrm{w} / \mathrm{v})$ acrylamide for the stacking gel and $7.5 \%(\mathrm{w} / \mathrm{v})$ acrylamide in the running gel. Samples were heated for $1 \mathrm{~min}$ at $90{ }^{\circ} \mathrm{C}$ in $62.5 \mathrm{~mm}$ Tris $/ \mathrm{HCl}(\mathrm{pH} 6.8), 2 \%$ SDS, $10 \%(\mathrm{v} / \mathrm{v})$ glycerol, $5 \%(\mathrm{w} / \mathrm{v})$ 2-mercaptoethanol and $0.001 \%(\mathrm{w} / \mathrm{v})$ bromophenol blue as the dye. Electrophoresis was carried out with a current of $3 \mathrm{~mA}$ per gel. The bands were fixed with $50 \%(\mathrm{w} / \mathrm{v})$ trichloroacetic acid overnight, and stained for $1 \mathrm{~h}$ at $37{ }^{\circ} \mathrm{C}$ with a $0 \cdot 1 \%(\mathrm{w} / \mathrm{v})$ Coomassie brilliant blue solution made up freshly in $50 \%$ trichloroacetic acid. Gels were diffusion destained in $7 \%(\mathrm{v} / \mathrm{v})$ acetic acid.

Gel permeation chromatography. A Sephadex G-100 column $(106 \times 1.5 \mathrm{~cm})$, equilibrated in $0.1 \mathrm{M}$-phosphate buffer $\mathrm{pH} 7.5$, was used to obtain the apparent molecular weight of the two polygalacturonases (Andrews, 1965). The recovery of enzymic activity after each experiment was always higher than $90 \%$.

Paper chromatography. The products formed by the action of polygalacturonase on sodium polygalacturonate were examined by descending paper chromatography. The reaction mixture, containing (in $1 \mathrm{ml}$ ) $0.6 \%(\mathrm{w} / \mathrm{v})$ sodium polypectate, $20 \mathrm{mM}$-citrate/phosphate buffer $\mathrm{pH} 5.0$ and 10 units of enzyme, was incubated at $30^{\circ} \mathrm{C}$. At various times, $25 \mu \mathrm{l}$ samples were taken and directly spotted on to the chromatographic paper; chromatograms were developed according to the method of Nasuno \& Starr (1966).

Carbohydrate assay. Carbohydrates in homogeneous PG-1 and PG-2 were determined by the anthrone method using glucose as standard (Spiro, 1966).

Protein determination. Protein concentration was measured according to Lowry et al. (1951) using bovine serum albumin as a standard.

Absorption of polygalacturonase by plant tissues. Discs ( $8 \mathrm{~mm}$ diam., $4 \mathrm{~mm}$ thick) of potato tubers, carrots, beets and French bean seeds were incubated with polygalacturonase allowing the components to reach equilibrium for $1 \mathrm{~h}$ at $23^{\circ} \mathrm{C}$. Enzyme activity was measured in the supernatant as described previously (Cervone et al., 1977a).

\section{RESULTS AND DISCUSSION}

\section{Enzyme purification}

All operations were carried out at 2 to $5^{\circ} \mathrm{C}$. The culture filtrate was first concentrated by ultrafiltration. The ultrafiltrate was dialysed overnight against $10 \mathrm{~mm}$-sodium acetate buffer pH 5.0 and loaded on to a CM-cellulose column $(21 \times 2.7 \mathrm{~cm})$ equilibrated with the same buffer. The column was washed with $140 \mathrm{ml}$ of buffer and then eluted with a linear 0 to $0.7 \mathrm{M}-\mathrm{NaCl}$ gradient $(380 \mathrm{ml}$ total volume). Polygalacturonase eluted as a symmetric peak at $0.32 \mathrm{M}-\mathrm{NaCl}$ (Fig. 1a). The peak fractions with the highest specific activity were pooled and subjected to extensive dialysis against $1 \%$ glycine. After isoelectric focusing in the $\mathrm{pH}$ range 6 to 8 , two distinct peaks were obtained (Fig. $1 b$ ). The isoelectric points of the two enzymes, denoted PG-1 and PG-2, were $6.41 \pm 0.03$ and $6.57 \pm 0.04$, respectively. The fractions corresponding to the two peaks were stored at $-20^{\circ} \mathrm{C}$ after extensive dialysis against $20 \mathrm{~mm}$-sodium acetate $\mathrm{pH} 5 \cdot 0$. Table 1 shows the purification achieved for 1.51 of culture filtrate.

\section{Enzyme homogeneity}

Purity of the two enzyme preparations was demonstrated by re-focusing, polyacrylamide gel electrophoresis and gel filtration. Only one peak was obtained when each enzyme was separately re-focused and no shift in the $\mathrm{pH}$ value at which each enzyme banded was 


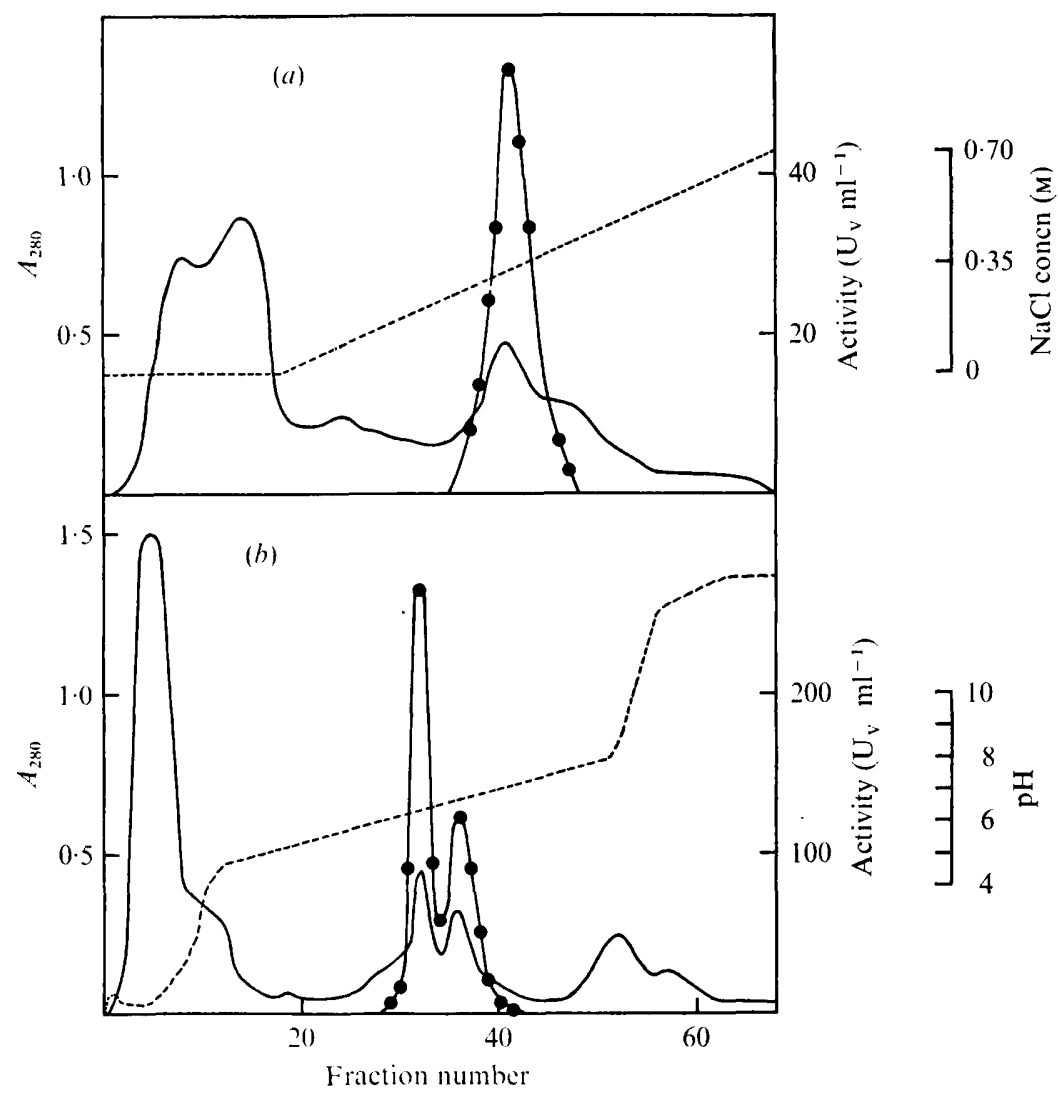

Fig. 1. (a) Elution profile of polygalacturonase activity from a CM-cellulose column; $7 \cdot 9 \mathrm{ml}$ fractions were collected and assayed for activity. (b) Isoelectric focusing of polygalacturonase isoenzymes; $40 \mathrm{ml}$ from the CM-cellulose column was mixed with the lighter component of the sucrose gradient; $2 \mathrm{ml}$ fractions were collected for $\mathrm{pH}$ and enzymic activity determinations. Other experimental details are given in the text. --O, Polygalacturonase activity; _bance at $280 \mathrm{~nm} ;----, \mathrm{NaCl}$ concentration $(a)$ or $\mathrm{pH}(b)$.

observed. SDS-polyacrylamide gel electrophoresis revealed only a single protein band from each preparation. Gel filtration experiments with the two enzymes gave symmetrical elution patterns with constant specific activity throughout the peak. PG-1 and PG-2 each consisted of a single polypeptide chain with an apparent molecular weight of 32000 .

\section{Enzyme properties}

The properties of the two isoenzymes are similar to those observed for polygalacturonases from phytopathogenic fungi (Bateman, 1972; Cervone et al., 1977b; Mussel \& Strouse, 1972; Strand, Corden \& MacDonald, 1976). Both enzymes showed optimal activity at pH 5.0 and their $K_{\mathrm{m}}$ values towards sodium polypectate $\left(0.8\right.$ and $0.85 \mathrm{~g} \mathrm{l}^{\mathbf{1}}$ for PG-1 and PG-2, respectively) were similar to those reported for polygalacturonases from Rhizoctonia fragariae (Cervone et al., 1977a).

Kinetic studies with the purified enzymes established that they can both be classified,as endopolygalacturonases (Bateman \& Millar, 1966). The high rate of viscosity decrease compared with the low rate of reducing-group increase during the enzymic breakdown of sodium polypectate (Fig. 2) showed that both enzymes hydrolysed the glycosidic bonds of the substrate in an 'endo' fashion. This was confirmed by analysis of the products of hydrolysis by paper chromatography. After $10 \mathrm{~min}$ incubation, hexa-, penta-, tetra- and 
Table 1. Purification of polygalacturonase from Trichoderma koningii

\begin{tabular}{|c|c|c|c|c|c|c|}
\hline Fraction & $\begin{array}{c}\text { Volume } \\
\text { (ml) }\end{array}$ & $\begin{array}{c}\text { Total } \\
\text { activity } \\
\left(U_{v}\right)\end{array}$ & $\begin{array}{l}\text { Total } \\
\text { protein } \\
(\mathrm{mg})\end{array}$ & $\begin{array}{c}\text { Specific } \\
\text { activity } \\
\left(\mathrm{U}_{\mathrm{v}} \mathrm{mg}^{-1}\right)\end{array}$ & $\begin{array}{l}\text { Yield } \\
(\%)\end{array}$ & $\begin{array}{l}\text { Purification } \\
\text { factor }\end{array}$ \\
\hline Filtrate & 1500 & 3750 & 825 & $4 \cdot 5$ & 100 & - \\
\hline UM-10 concentration & 150 & 2300 & 87 & $26 \cdot 4$ & 61 & $5 \cdot 9$ \\
\hline $\begin{array}{l}\text { CM-cellulose } \\
\text { chromatography }\end{array}$ & 40 & 1472 & $14 \cdot 7$ & $100 \cdot 1$ & 39 & $22 \cdot 2$ \\
\hline \multirow{2}{*}{ Electrofocusing } & 6 & 930 & 3.72 & 250 & $24 \cdot 8$ & $55 \cdot 5$ \\
\hline & 4 & 460 & $1 \cdot 84$ & 250 & $12 \cdot 2$ & $55 \cdot 5$ \\
\hline
\end{tabular}

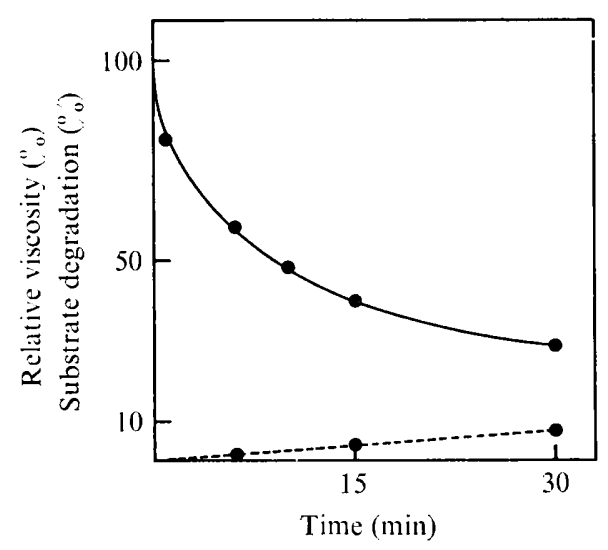

Fig. 2. Viscosity change and hydrolysis of sodium polypectate by PG-1 as a function of time: similar results were obtained with PG-2. Details are given in Methods. - - , Relative viscosity (\%); -.-., hydrolysis of glycosidic bonds ( $\%$ of nominal monomer concentration).

trigalacturonic acids were present. After $1 \mathrm{~h}$, the higher molecular weight oligouronides had disappeared, and more trigalacturonic acid, as well as trace amounts of digalacturonic acid, were observed. After longer times (10 and $24 \mathrm{~h}$ ) only tri- and digalacturonic acids were detectable in the chromatogram.

PG-1 and PG-2 from T. koningii were both glycoproteins and had carbohydrate contents of 0.033 and $0.062 \mathrm{mg}$ sugar ( $\mathrm{mg}$ protein) $)^{-1}$, respectively. This could account for the difference in their isoelectric points. The association of carbohydrates with purified polygalacturonase has been reported previously (Cervone et al., 1977b; Strand et al., 1976; Wang \& Keen, 1970) and it has been suggested that the glycosidic moiety of the enzyme mediates recognition of the host by phytopathogenic fungi (Cervone et al., 1977a). The two polygalacturonase isoenzymes from $T$. koningii, which does not cause disease in plants, were glycoproteins with similar properties to the corresponding enzymes produced by phytopathogenic fungi. Nevertheless, when PG-1 and PG-2 were incubated with different plant tissues, they were not absorbed by any of them. These results suggest that these enzymes, though catalytically similar to phytopathogenic polygalacturonases, are not able to bind to host plant tissues and, therefore, exhibit a difference in structure that could be responsible for the lack of pathogenicity of $T$. koningii towards plants.

We thank Professors C. Noviello and A. Rambelli for helpful discussions. We are also indebted to Professor R. K. S. Wood for critically reading the manuscript. This work was partially supported by a grant from the CNR Group 'Patologia Piante Ortensi'. 


\section{REFERENCES}

ANDrews, P. (1965). The gel filtration behaviour of proteins related to their molecular weight over a wide range. Biochemical Journal 91, 595-606.

BATEMAN, D. F. (1972). The polygalacturonase complex produced by Sclerotium rolfsii. Physiological Plant Pathology 2, 175-184.

Bateman, D. F. \& Millar, R. L. (1966). Pectic enzymes in tissue degradation. Annual Review of Phytopathology 4, 119-146.

Cervone, F., Scala, A. \& Scala, F. (1977a). Polygalacturonase from Rhizoctonia fragariae. Further characterization of two isoenzymes and their action towards strawberry tissues. Physiological Plant Pathology (in the Press).

Cervone, F., Scala, A., Foresti, M., Cacace, M. G. \& Noviello, C. $(1977 b)$. Endopolygalacturonase from Rhizoctonia fragariae. Purification and characterization of two isoenzymes. Biochimica et biophysica acta 482, 379-385.

Fanelli, C. \& Cervone, F. (1977). Polygalacturonase and cellulase production by Trichoderma koningii and Trichoderma pseudokoningii. Transactions of the British Mycological Society 68, 291-294.

LAEMMLI, U. K. (1970). Cleavage of structural proteins during the assembly of the head of bacteriophage T4. Nature, London 227, 680-685.
Lowry, O. H., Rosebrough, N. J., FarR, A. L. \& Randall, R. J. (1951). Protein measurement with the Folin phenol reagent. Journal of Biological Chemistry 193, 265-275.

MILleR, G. L. (1959). Use of dinitrosalicylic acid reagent for determination of reducing sugar. Analytical Chemistry 31, 426-427.

Mussel, H. W. \& Strouse, B. (1972). Characterization of two polygalacturonases produced by Verticillium albo-atrum. Canadian Journal of Biochemistry 50, 625-632.

Nasuno, S. \& StarR, M. P. (1966). Polygalacturonase of Erwinia carotovora. Journal of Biological Chemistry 241, 5298-5306.

SpIRo, R. G. (1966). Analysis of sugars found in glycoproteins. Methods in Enzymology 8, 3-26.

Strand, L. L., Corden, M. E. \& MacDonald, D. L. (1976). Characterization of two endopolygalacturonase isoenzymes produced by Fusarium oxysporum f.sp. lycopersici. Biochimica et biophysica acta 429, 870-883.

WANG, M. C. \& KeEN, N. T. (1970). Purification and characterization of endopolygalacturonase from Verticillium albo-atrum. Archives of Biochemistry and Biophysics 141, 749-757. 